\title{
Improving Students' Mathematical Critical Thinking Abilities Through the Problem Solving Method on the Sequences and Series Course
}

\author{
Dahliana ${ }^{1, a}$, Marhami1 $1, b$, and Mursalin ${ }^{1, c^{*}}$ \\ ${ }^{1}$ Department of Mathematics Education, Malikussaleh University, Aceh Utara, Indonesia \\ a adahli363@gmail.com; b marhami@unimal.ac.id; c mursalin@unimal.ac.id \\ *Corresponding Author: mursalin@unimal.ac.id
}

How to Cite : Dahliana, D., Marhami, M., Mursalin, M., (2019). Improving Students' Mathematical Critical Thinking Abilities Through the Problem Solving Method on the Sequences and Series Course. International Journal for Educational and Vocational Studies, 1 (7), 813-816. DOI: https://doi.org/10.29103/ijevs.v1i7.2571

\section{ARTICLE HISTORY}

Received: 17 September 2019

Revised: 24 October 2019

Accepted: 8 November 2019

\section{KEYWORDS}

Mathematical Critical Thinking; Problem Solving Methods;

Sequence And Series;

\section{ABSTRACT}

This study aims to determine the improvement of students' mathematical critical thinking abilities through problem solving methods. This study was hold at MAN 3 Bireuen (High School Level) in the 2019/2020 school's year. The research method was a quasi-experimental study design nonrandomized Pre-test Post-test Control Group Design. The population of the study were all students of Class XI MAN 3 Bireuen with purposive sampling technique. The study sample was to 30 students for the experimental class and 28 students for the control class. The skill increasing was calculated using normalized gain. Data were analyzed using the $t$ test. The results showed that students' critical thinking skills mathematically taught through problem solving methods is better than students mathematical critical thinking skills taught through conventional learning.

\section{INTRODUCTION}

The development of science and technology is now essential, especially in education. Education is one crucial factor for a country. Because education can produce generations that can advance the country. If the next generation is poorly educated, the country is less able to compete with other developed countries. Education has a goal that the successor of the State has high competence and can compete with the next generation of other countries (Martiana, 2015: 1). In improving the quality of education, it is necessary to change the mindset that will be the basis of the implementation of knowledge in the future. Improving the quality of education is realized through the learning process. At this time, there is still a learning process that is only focused on the teacher and less focused on students. As a result, teaching and learning activities place more emphasis on teaching, not on learning. Teaching activities are more in favor of the interests of those who teach (teachers) while learning activities are more in favor of those who learn (students).

The method that is expected to be suitable for applying to mathematics learning and can improve students' mathematical critical thinking skills is the Problem Solving method. Problem Solving Method is the use of methods in learning activities by training students to deal with various problems, either personal or individual problems or group problems, to be solved alone or together (Ayuningsih, 2013: 18).

Polya (in Rahmawati, 2014: 4) provides four main steps in the Problem-Solving method, including understanding the problem, compiling a settlement plan, implementing a settlement plan, re-examining the settlement that has been carried out. Of the four steps, it is very easy to make efforts to bring up students' mathematical critical thinking skills.

To see the extent and efficacy and importance of the Problem Solving method in order to improve students' mathematical critical thinking skills, it needs to be compared with other learning. Because so far, the learning that is often applied is conventional learning, so the learning is used as a comparison. However, conventional learning is not able to improve students' mathematical critical thinking skills; it's just that all learning methods have advantages and disadvantages of each.

Noting the Problem-Solving method and Conventional learning have advantages in getting data that at MAN 3 Bireuen (High School Level) that school has low critical thinking skills, then a study was conducted on improving the Problem-Solving method and conventional learning in 
improving students' mathematical critical thinking skills.

The research questions in this study are is whether the increase in students' mathematical critical thinking skills taught through the Problem Solving method is better than the mathematical critical thinking skills taught through conventional learning in row material and series in class XI MAN 3 Bireuen.

While the study aims to find out the improvement of students' mathematical critical thinking skills taught through the Problem Solving method is better than the mathematical critical thinking skills taught through conventional learning in a row and series material in class XI MAN 3 Bireuen.

\section{METHODS}

This type of research used in this research is quantitative research with quasi-experimental methods. Learning is divided into two types, namely learning by using the Problem Solving method and conventional learning. This study uses a Nonrandomized Pretest Posttest Control Group Design research design.

Table 1. Research Design

\begin{tabular}{cccc}
\hline Group & Pre-test & Treatment & Post-test \\
\hline Experiment & $\mathrm{T} 1$ & $\mathrm{X}$ & $\mathrm{T} 2$ \\
\hline Control & $\mathrm{T} 1$ & - & $\mathrm{T} 2$ \\
\hline
\end{tabular}

This study was conducted in March 2019. The population in this study were all students of class XI MAN 3 Bireuen in the 2019 school year consisting of 8 classes. Through the Purposive Sampling technique, two classes have been chosen from the population, namely the Natural Sciences class as the experimental class and the Natural Sciences class as the control class.

The test instrument used in this research is a test item to measure students' mathematical critical thinking skills consisting of 4 essay items given in the form of pretest and posttest. Mathematical critical thinking skills that will be measured in the way of the ability to identify problems, take steps to solve, clarify a statement, and make conclusions. This critical thinking ability has been tested by Martiana (2015) in her special research in learning mathematics. All statistical tests were carried out using the help of the SPSS 18 Software program.

\section{RESULTS AND DISCUSSION}

The data used to calculate the increase in students' mathematical critical thinking skills is the $n$-gain value data.

\subsection{Results}

The following is a table that illustrates the pretest, posttest, and normalized gain (n-gain) descriptive data for tests of mathematical critical thinking ability. The data used to calculate the increase in students' mathematical critical thinking skills is the $\mathrm{n}$-gain value data.

Table 2. Student's Mathematical Critical Thinking Score Data

\begin{tabular}{|c|c|c|c|c|c|c|c|c|c|}
\hline \multirow{2}{*}{ Abilities } & \multirow{2}{*}{ Score } & \multicolumn{4}{|c|}{ Experiment } & \multicolumn{4}{|c|}{ Control } \\
\hline & & $\mathrm{n}$ & $\overline{\mathrm{x}}$ & $\mathrm{s}$ & $\%$ & $\mathrm{~N}$ & $\overline{\mathrm{x}}$ & $\mathrm{S}$ & $\%$ \\
\hline \multirow{3}{*}{ Critical Thinking } & Pre-test & 30 & 4,43 & 1,83 & 0,37 & 28 & 4,11 & 2,36 & 0,34 \\
\hline & Post-test & 30 & 10.60 & 1,69 & 0,88 & 28 & 9,11 & 2,40 & 0,67 \\
\hline & N-gain & 30 & 0,82 & 0,18 & & 28 & 0,65 & 0,25 & \\
\hline
\end{tabular}

Based on the table 2, it can be seen that the difference in the average value of the pretest of the experimental class is greater than the average value of the control class pretest, this shows that the score of students' mathematical critical thinking ability applied using the Problem Solving method is more varied and spreads on the class averages.

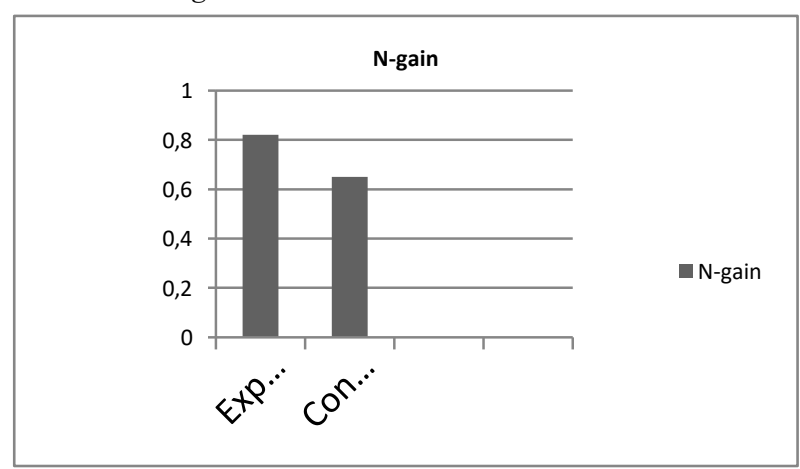

Figure 1. N-Gain Ability Score Value of the Students' Mathematical Critical Thinking
Based on Figure 1. the N-gain value of the experimental class was 0.82 , while that of the control class was 0.65 . The results of this study indicate that the application of the Problem Solving method shows an increase in students' mathematical critical thinking skills.

The normality test aims to test whether the data obtained has a normal distribution or not. The normality test of the n-gain score in this study uses the Shapiro-Wilk technique in which the sig value. ( $p$-value) $<\alpha(\alpha=0.05)$, then $\mathrm{H}_{0}$ is rejected and if the value of sig. $(p$-value $) \geqslant a \quad(a=0.05)$, then $\mathrm{H}_{0}$ is accepted.

In Table 3 , it can be seen that the $\mathrm{N}$-gain score of mathematical critical thinking ability of experimental class students has a Sig. $<\alpha=0.05$ so $\mathrm{H}_{0}$ is rejected. This shows that the $\mathrm{N}$-gain score data of mathematical critical thinking ability of experimental class students are not normally distributed. While the $\mathrm{N}$-gain score of mathematical critical thinking ability of control class students has a Sig. $>a=0.05$, so $\mathrm{Ha}$ is rejected. This 
shows that the $\mathrm{N}$-gain score data of mathematical critical thinking ability of control class students are normally distributed.

Based on the results obtained from the normality test of students' mathematical critical thinking abilities, one class of n-gain values is not normally distributed then it is continued with the non-parametric test that is the Mann-Whitney test.

Table 3. Data on Normality Test Results for N-gain Data on Students' Mathematical Critical Thinking Abilities

\begin{tabular}{ccccc}
\hline \multirow{2}{*}{ Classes } & \multicolumn{3}{c}{ Shapiro-Wilk } & \multicolumn{2}{c}{ Conclusion } \\
\cline { 2 - 5 } & Statistics & Df & 0,001 & Ho Rejected \\
\hline Experiment & 0,867 & 30 & 0,072 & Ha Rejected \\
\hline Control & 0,933 & 28 &
\end{tabular}

Table 4. Non-Parametric Test Result Data

\begin{tabular}{ccc}
\hline Statistics & Value & Conclusion \\
\hline Mann-Whitney U & 254,000 & \multirow{2}{*}{ Ho Rejected } \\
\hline Asymp. Sig. (2-tailed) & 0.009 & \\
\hline
\end{tabular}

Based on Table 4, it can be seen that the value of Sig. < $a=0.05$, so $\mathrm{H}_{0}$ is rejected. That is, increasing students' mathematical critical thinking abilities taught through the Problem Solving Method is better than the mathematical critical thinking abilities of students taught through conventional learning significantly.

\section{Discussion}

The results showed that the mathematical critical thinking ability of the experimental class students was higher than the mathematical critical thinking ability of students in the control class. This shows that students in the experimental class have higher mathematical critical thinking skills than the control class. Students' critical thinking skills in learning in the experimental class have increased. This can be seen from the answers of students in analyzing cases given to students. By using the problem solving learning model in small groups students are guided to analyze existing problems with their own thinking skills. It is expected that with the increased ability to think critically, students can use to analyze the problems that occur in the surrounding environment. This shows that students in the experimental class have higher mathematical critical thinking skills than the control class.

Mathematical critical thinking skills of students can also be seen from the average value obtained during the learning process. In the experimental class the average value of $\mathrm{N}$-gain obtained by students is 0.82 , while in the control class the average value of $\mathrm{N}$-gain obtained by students is 0.65. This statement illustrates that learning with the Problem Soving method can develop students' mathematical critical thinking skills. This is similar to the research conducted by Sartika (2011) Medan State University (UNIMED). The research shows that students' mathematical critical thinking skills with cooperative learning are better than conventional learning.

\section{CONCLUSION}

Based on the results of the study on mathematics learning with Problem Solving method on students' mathematical critical thinking skills, obtained several conclusions as follows:

1. Students' mathematical critical thinking abilities using Problem Solving learning methods are higher than students' mathematical critical thinking abilities that are given conventional learning. The four indicators of students' mathematical critical thinking ability with the Problem Solving method have an average higher than the average mathematical critical thinking ability with conventional learning.

2. Increasing students' mathematical critical thinking skills by using the Problem Solving method is better than increasing students' mathematical critical thinking skills that are applied to conventional learning.

\section{REFERENCES}

Arikunto, S. (2013). Prosedur Penelitian Suatu Pendekatan Praktik. Jakarta: PT Rineka Cipta.

Ayuningsih. S. (2013). Pengaruh Penggunaan Metode Pembelajaran Problem Solving terhadap Kemampuan Berpikir Kreatif Matematika Siswa SMA Handayani. Skripsi. Riau: Universitas Islam Negeri Sultan Syarif Kasim.

Karim, A. (2011). Penerapan Metode Penemuan Terbimbing dalam Pembelajaran Matematika untuk Meningkatkan Pemahaman Konsep dan Kemampuan Berpikir Kritis Siswa SD. Jurnal Penelitian Pendidikan. 1(1): 21-32

Marhami. (2016). Pengaruh Strategi Pembelajaran Konflik Kognitif Terhadap Kemampuan Pemahaman Relasional dan Komunikasi Matematis Serta Self-Regulation siswa SMP. Tesis. Bandung: Universitas Pendidikan Indonesia.

Martiana, D. (2015). Meningkatkan Kemampuan Berpikir Kritis Matematis Siswa dengan Menggunakan Model Pembelajaran Kooperatif Tipe Team Assited 
Individualization (TAI). Skripsi. Jakarta: Universitas Islam Negeri Syarif Hidayatullah.

Perdana. M. P. (2014). Pengaruh Metode Problem Solving terhadap Hasil Belajar Siswa Kelas VIII Mts. Assyafi'iyah Gondang pada Materi Hubungan Sudut Pusat, Panjang Busur, dan Luas Juring dalam Pemecahan Masalah. Skripsi. Universitas Institut Agama Islam Negeri Tulungagung.

Rahmawati. N. D. (2014). Pembelajaran Matematika dengan Strategi Heuristik Polya Untuk Meningkatkan Kemampuan Berpikir Kritis Matematis Siswa Kelas VIII C SMP Negeri 6 yogyakarta. Skripsi. Universitas Negeri Yogyakarta.

Sartika, I. (2011). Pengaruh Pendekatan Pembelajaran Kooperatif Terhadap Kemampuan Berpikir Kritis dan Berkomunikasi untuk Siswa SMP. Tesis. Universitas Negeri Medan.

Syahbana. A. (2012). Peningkatan Kemampuan Berpikir Kirtis Matematis Siswa SMP Melalui Pendekatan Contextual Teaching And Learning. Jurnal Pendidikan Matematika. 1(2): 45-57. 